\title{
Do Forensic Expertise, Professional Skepticism and Time Pressure Affect Fraud Detection?
}

\author{
Sigit Handoyo ${ }^{1}$, Widya Kusuma Wardani ${ }^{2}$ \\ \{sigit.handoyo@uii.ac.id ${ }^{1}$, kusumawidyawar@gmail.com ${ }^{2}$ \} \\ Accounting Department, Universitas Islam Indonesia ${ }^{1}$, PT. Reksa Multi Usaha ${ }^{2}$
}

\begin{abstract}
Indonesia's score in the 2017 Corruption Perception Index (CPI) Index has stagnated with a score of 37 since 2016, meaning that the quality of eradicating corruption is low. The role of auditor, especially government internal auditor, has not been optimal in detecting fraud. Therefore, fraud detection is very important for auditors to reduce corruption in Indonesia. The purpose of this research is to find the influence of forensic expertise, professional skepticism and time pressure to fraud detection. This research was done in The Finance and Development Supervisory Agency (BPKP) of the Daerah Istimewa Yogyakarta Province (DIY). In this research, sample of 55 respondents were selected using convenience sampling method. Eeighty eight questionnaires administered then 60 questionnaires were returned and 55 questionnaires were feasible to use and were examined using the multiple linear regression model. Analysis tool used in this research was the SPSS 21. The result of the research showed that forensic expertise and professional skepticism affect significantly on fraud detection. While the time pressure does not affect to fraud detection.
\end{abstract}

Keywords: Forensic Expertise, Fraud Detection, Professional Skepticism, Time Pressure

\section{Introduction}

Indonesia's Corruption Perseption Index (CPI) score based on the Transparency International survey, Indonesia's score in the 2017 Index (CPI)[1] has stagnated with a score of 37 since 2016. In terms of ranking, Indonesia is ranked 96 out of 180 surveyed. The results show that there was no improvement in Indonesia in eradicating corruption from the previous year.

Based on a survey conducted by Transparency International Indonesia in 12 major cities in Indonesia in 2017, North Jakarta had the highest GPA with a value of 73.9 points. It can be concluded that business operators in North Jakarta rate the commitment of local governments in eradicating corruption is very well. While the lowest GPA of the city of Medan with a value of 37.4 points, where there is still a lot of corruptions.

Presidential Instruction (Inpres) No. 5 of 2004 concerning the Acceleration of Corruption Eradication contains the government's actions that instructs all central and regional authorities to carry out any steps to eradicate corruption. The designation of corruption as an extraordinary crime makes the government feel it is necessary to form a special body that is independent and free from any power. The special body is the Corruption Eradication Commission (KPK) which is authorized to conduct coordination and supervision, including conducting investigations. In addition, the government also gave the power to the The Financial and Development Supervisory Agency (BPKP) to handle cases that are indicated corruptions.

In order to follow up on the various frauds that have occurred, the role of the forensic auditor is needed to detect fraud. DIY is one of 10 provinces which this year has become the location of efforts to prevent corruption, from 2016 to the end of 2017. However, in the last three years the KPK RI has received complaints from the public about 192 reports of corruption. This happens because most auditors do not yet have the knowledge and ability to take preventative actions. Therefore we need forensic expertise in detecting fraud in order to create a government that is free of corruption. The skills and abilities required are forensic expertise and professional skepticism that must be possessed by the auditor.

Skepticism is a critical attitude in assessing the reliability of assertions or the evidence obtained, so that in conducting the audit process an auditor has sufficiently high confidence in an assertion or evidence that he has obtained and also considers the adequacy and suitability of the evidence obtained. Each auditor has expertise in finding fraudulent cues in detecting different frauds due to several factors, 
for example the expertise possessed by each auditor differs with a different skepticism and the situation that the auditor must face in working is the presence of time pressure. Auditors are not only required to work professionally, but also must be in accordance with the stipulated time budget. Limited time budget of course becomes a special pressure for the auditor. Time budget pressures produce poor results for the auditor's performance.

Several studies have been conducted to examine how the influence of forensic expertise, professional skepticism and time pressure on the detection of fraud. However, previous studies have varied results. Verwey and Asare's (2016)[2] research results showed that auditors who had forensic expertise given high risk assessments and under budget pressure when planning audit procedures, were more effective than auditors without forensic expertise. According to research conducted by Ramadhany (2015)[3] showed that auditor professional skepticism had a significant effect on the auditor's ability to detect fraud. According to research by Anggriawan (2014)[4] which showed that time pressure negatively affects the ability of auditors to detect fraud. However, different research results were found in a study conducted by Pangestika (2014)[5] that time budget pressure had no effect on fraud detection. And the results of different studies conducted by Rustiarini (2013)[6] who found that time pressure had no effect on auditor job satisfaction and dysfunctional behavior that could influence auditors in detecting fraud.

The purpose of this study is to examine the extent of the influence of forensic expertise, professional skepticism and time pressure on the detection of fraud on auditors working in the Financial and Development Supervisory Agency in the Yogyakarta Special Representative.

\section{Literature Review}

\subsection{Attribution Theory}

Attribution theory is first put forward by Heider (1958)[7]. This theory suggests that when observing an individual's behavior, we try to determine whether the behavior is caused by internal factors or external factors. Internal behavior is behavior that is believed to be influenced by an individual's personal control, such as ability and effort. While the behavior caused by external factors is considered as a result of external causes, namely the individual has behaved in such a way caused by certain situations, such as task difficulties (Kreitner, 2014: 203)[8].

This theory refers to how a person explains the causes of other people's behavior or himself which will be determined whether from internal factors such as nature, character, attitude, or external such as the pressure of certain situations or circumstances that will affect the behavior of individuals. Attribution theory explains the understanding of a person's reaction to events around them, by knowing their reasons for the events experienced. Attribution theory also explains that there are behaviors related to individual attitudes and characteristics, so it can be said that only by looking at their behavior will be known the attitude or characteristics of the person and can also predict a person's behavior in dealing with certain situations (Sastiana, 2016)[9].

In this study attribution theory is used to explain how the internal auditor's influence are forensic expertise and professional skepticism of the auditor, and external factors namely time pressure can affect the auditor's actions in detecting fraud. As has been explained above where the three things above are factors that encourage an auditor to achieve the effectiveness of the implementation of audit procedures in disclosure of fraud.

With the forensic expertise possessed by the auditor, the auditor must use his/her forensic expertise to include consideration in finding fraud findings and be able to formulate his/her opinion properly so as to maximize the auditor in detecting fraud. To achieve the expected results, the auditor must also use his/her professional skepticism so that he/her can obtain and evaluate sufficient evidence to provide an appropriate and impartial audit opinion in the detection of fraud. And there are time pressures that occur, whether there is influence for the auditor in carrying out effective audit procedures to detect fraud

\subsection{Fraud Detection}

According to W. Steve Albrecht and Chad D Albrecht (2004)[10] in the book of Fraud Examination fraud and Prevention, fraud is a common understanding and includes a variety of ways that can be used by means of violence by one person to benefit from others through improper conduct. There are no definitions or rules that can be used as a general understanding in interpreting fraud which 
includes ways that contain a sudden, deceptive, clever, and dishonest nature that is used to trick someone. The only limit to knowing the above understanding is that it limits the nature of human dishonesty. Fraud is an act that is contrary to the truth that was made intentionally, with the aim to obtain something that is not the right of the culprit (Pangestika, 2014)[5].

According to the International Standards on Auditing (ISA)[11] section 240 fraud is defined as an intentional act by members of the company's management, parties who play a role in corporate governance, employees or third parties who deceive or cheat to obtain unfair or illegal profits. The two main categories of fraud are fraudulent financial reporting and misuse of assets (Arens et al., 2006: 430)[12]. Fraudulent financial reporting is a misstatement or omission of the amount or deliberate disclosure with the intention of deceiving the users of the financial statements, while the misuse of assets is fraud involving the theft of the entity's assets (Anggriawan, 2014)[4].

According to the 2006 Examination Manual of the Association of Certified Fraud Examiner (ACFE)[13], fraud consists of four major groups namely:

1. Fraud in financial statements

Fraud in financial statements includes actions taken by officials or executives of a company or government agency to cover up the actual financial condition by conducting financial engineering in the presentation of financial statements for profit.

2. Corruption

This type of fraud is the most difficult to detect because it involves cooperation with other parties such as bribery and corruption. This type of fraud often cannot be detected because the parties who collaborate enjoy the benefits. Corruption includes bribery, conflict of interest, illegal gratuity, and economic extortion.

3. Misuse of assets (asset misappropriation)

Misuse of assets includes the misuse / theft of assets or property of companies or other parties. This is the easiest form of fraud to detect because it is tangible or can be measured / calculated.

4. Computer-related fraud

Cheating caused by the development of crime in the field of computers. For example 1) Adding, removing, or changing false entries or data entry, 2) Damaging the program by taking money from many accounts in small amounts, 3) Incorrectly posting or posting only part of the transaction.

Detecting fraud is a process to be able to find or reveal deviant actions that are done intentionally and result in a misstatement of a financial statement. Not all auditors can detect and find fraud. Because in general evidence of fraud can only be known through signs, symptoms or signals from actions that are suspected of causing the fraud. Most of the evidence of fraud is evidence that is indirect. Clues to cheating are usually indicated by the appearance of symptoms such as changes in lifestyle or behavior, suspicious documentation, complaints from customers or suspicion from coworkers (Anggriawan, 2014)[4].

Initially, this fraud will be reflected through the emergence of certain characteristics, both those that are environmental conditions as well as one's behavior. Characteristics that are specific conditions or situations, behavior or condition of a personal person is called the Red Flag indicators. Although the emergence of the red flag is not always an indication of fraud, but this red flag usually always appears in every case of fraud that occurs (Pangestika, 2014)[5]. The ability to detect fraud is related to the ability to understand the symptoms of fraud (red flags). To understand the symptoms of cheating (red flags), an auditor must have sufficient expertise in identifying indicators of fraud (Muchlis, 2015)[14].

Karyono (2013: 92)[15] explained the detection of fraud as having stages in it, the initial stage in detecting fraud is studying the activities of organizations and business units. At this stage the aim is to find out whether an organization has implemented internal controls. An internal control function to prevent fraud also functions in detecting fraud. After studying the activities of the organization we can identify frauds that occur. The next stage is to learn the signs of fraud, which are oddities, anomalies and deviations. After the two stages, analysis and evaluation are carried out. If there is a large indication of fraud then an investigative exercise will be carried out.

Fraud detection includes the identification of fraud indicators that require the auditor's follow-up to investigate. Ramadhany (2015)[3] stated that the detection of fraud was not an easy task carried out by the auditor. Based on the available literature, four identified factors can be mapped that make fraud 
detection difficult to do so the auditor fails to detect. These causative factors are characteristics of fraud, understanding auditing standards regarding fraud detection, an audit work environment that reduces audit quality, and audit methods and procedures that are not effective in detecting fraud.

\subsection{Expertise}

The meaning of expertise in the Big Indonesian Dictionary is proficiency in a science (intelligence, work). Expertise is an important element that must be possessed by an auditor to work professionally. This is confirmed in the first general standard of SA Section 210 that the audit must be carried out by someone or more who has sufficient expertise and technical training as an auditor (Indonesia, I. A. P., n.d)[11].

Expertise can be concluded as a positive basis owned by a forensic auditor to support his assignment in calculating state losses, disclosure of hidden cases, as well as expert witnesses in court that require critical thinking, deductive analysis, communication skills in oral and written, etc. other.

Karyono (2013: 140)[15] explains that forensic auditors must have sufficient knowledge about knowledge of cheating, knowledge of laws and regulations, competent in investigation, understand psychological theory, understand other important theories about criminal behavior, understanding control theory, communication skills, formulation of professionalism, independence and objectivity (PIO Formulation), and right personnel under review.

Basically a forensic auditor has extensive knowledge of applicable accounting standards and their application and legal knowledge as necessary, both civil and criminal law. This knowledge must be obtained not only from college, but also from experience in practice in the field and through continuous professional training and education. This emphasizes the importance of forensic auditor expertise in conducting audits and assessing the risk of fraud (Kayo, 2013: 22)[16].

Bhasin (2013)[17] elaborated or extended some of the knowledge and skills revealed by DiGrabriele (2008)[18] as a basis for research by using nine items of competence of forensic auditor expertise used in assessing differences in perceptions of accounting academics, accounting practitioners, and users of forensic auditor services, namely :

1. An important skill for a forensic auditor is deductive analysis which is the ability to analyze discrepancies that occur in financial statements, i.e. events that are not in accordance with reasonable conditions.

2. The expertise that is important for a forensic auditor is critical thinking which is the ability to distinguish between opinions and facts.

3. An important skill for a forensic auditor is solving unstructured problems which is the ability to approach each situation (especially unnatural situations) through an unstructured approach. In this case the auditor must be able to provide solutions to solving unstructured problems.

4. An important skill for a forensic auditor is investigation flexibility which is the ability to conduct audits outside the applicable provisions or procedures.

5. The expertise that is important for a forensic auditor is analytic expertise which is the ability to check what should be (what should be available) is not what already exists (what is already available).

6. An important skill for a forensic auditor is oral communication which is the ability to communicate effectively verbally through expert testimony and general explanations about the basics of opinion.

7. An important skill for a forensic auditor is written communication which is the ability to communicate effectively with writing through reports, charts, pictures and schedules about the basics of opinion.

8. The expertise that is important for a forensic auditor is legal knowledge which is the ability to understand basic legal processes.

9. Expertise that is important for a forensic auditor is composure which is the ability to maintain a calm attitude even in stressful situations.

\subsection{Forensics}

Webster's dictionary describes the word forensics like objects used in court. According to Priantara (2013)[19] Forensics means relating to, used in, or appropriate for legal institutions or for public discussion or for argumentative evidence or relating to the application of science to legal matters. 
So the term forensics in the accounting profession is related to the relationship and application of financial facts with legal issues. The rapid growth in the forensic accounting profession is inseparable from fraud or corruption that has never been lost even until now has not been sharply reduced but instead became complex. Forensic science is the application of science to criminal investigation in order to find evidence that can be used in solving criminal cases (Sudaryati, 2010)[20].

\subsection{Forensic Auditor}

According to the BPKP forensic audit is a combination of expertise in accounting, auditing and law. Forensic audit results are used in litigation or other forms of law. A forensic auditor must have academic and empirical expertise relating to the litigation process and relating to investigative audits, calculation of losses and providing expert statements at court proceedings (Priantara, 2013)[19].

Forensic auditors are defined as the science of gathering and presenting information in a form and format that is acceptable to the legal system in court against economic offenders (Kayo 2013: 46)[16]. Thus, forensic audits can be defined as the act of analyzing and comparing conditions in the field with criteria, to produce information such as how long the fraud was committed, how to commit the fraud, how much is it, where it was done, and who the perpetrators or quantitative evidence could be used before the court (Alabdullah et el. 2013)[21].

The purpose of forensic auditing is very specific so that the preparation of the program and the implementation of the audit is very different from the usual audit. The forensic audit program must be directed to gather sufficient and competent evidence so that the criminal case being handled can be revealed. Therefore, in its implementation, auditors with special characteristics are needed. Therefore, in its implementation, auditors with special characteristics are needed. A forensic auditor is required to be able to look out and trace beyond the visible numbers, and be able to relate it to a developing business situation in order to reveal accurate, objective information, and to find irregularities (Sudaryati, 2010)[20].

The purpose of a forensic audit is to detect or prevent various types of fraud. The techniques used in forensic audits have been specifically directed to find fraud. Many of these techniques are detecting fraud more deeply and even to the level of finding out who perpetrators of fraud. Therefore, forensic audit techniques are similar to the techniques used by detectives to find perpetrators of criminal acts (Sastiana, 2016)[9].

\subsection{Professional Skepticism}

Tuanakotta (2015: 323)[22] explained professional skepticism is the auditor's obligation to use and maintain professional skepticism, throughout the assignment period. Especially vigilance over the possibility of fraud.

Professional skepticism is interpreted as an attitude that does not easily believe audit evidence presented by management, an attitude that always questions and evaluates audit evidence critically. Professional skepticism is very important to be owned by the auditor in order to obtain strong information, which will be used as a basis for relevant audit evidence that can support the provision of opinions on the reasonableness of the financial statements (Adnyani et al., 2014)[23].

Professional skepticism needs to be possessed by the auditor especially when obtaining and evaluating audit evidence. The auditor must not simply assume that management is dishonest, but the auditor must also not assume that management is entirely honest. In ISA No. 200 said that the attitude of professional skepticism means the auditor makes a critical assessment, with a mind that always questions of the validity of the audit evidence obtained, be alert to audit evidence that is contradictory or raises questions regarding the reliability of the document, and provide responses to questions and other information obtained from management and related parties (Noviyanti, 2008)[24].

Auditors' professional skepticism is influenced by many things, such as experience, ethical awareness, audit situation and professionalism. Professional standards require that auditors not simply assume that management is dishonest, but also may not assume honest management. So the auditor is asked not to have too high a level of trust in his client. But in practice, an auditor often encounters conflicts related to the level of trust in the client (Ramadhany, 2015)[3].

The auditor evaluates audit evidence by conducting an audit test to obtain the truth about the symptoms of possible fraud (fraud). In gathering evidence and evaluating audit evidence, the auditor 
uses his/her knowledge, expertise and abilities carefully and thoroughly. Because auditors are required to have a high attitude of professional skepticism over the possibility of fraud, even though such fraud is not necessarily the case (Noviyanti, 2008)[24].

Noviyanti (2008)[24] said that auditor's professional skepticism is influenced by social factors (trust), psychological factors (assessment of fraud risk) and personal factors (personality).

1) Trust

Independent auditors who conduct audits in the field will carry out social interactions with clients, management and client staff. This social interaction will give rise to the trust of the auditor to the client. Noviyanti (2008)[24] states that trust in the auditor-client relationship will affect professional skepticism. The auditor's low level of trust in the client will increase the auditor's skepticism, while the auditor's level of trust that is too high will reduce his professional skepticism.

2) Fraud Risk Assessment

Noviyanti (2008)[24] proves that auditor professional skepticism is influenced by fraud risk assessment provided by the auditor's supervisor (auditor in charge) as a guide in conducting audits in the field. Auditors who are given a low fraud risk assessment become less skeptical compared to auditors who are given a high fraud risk assessment.

3) Personality

A person's personality type is also thought to influence his professional skepticism. Noviyanti (2008)[24] recognizes that attitudes have a genetic basis. Attitudes that have a genetic basis tend to be stronger than attitudes that do not have a genetic basis. So it can be said that individual personality differences form the basis of a person's attitude including his attitude of professional skepticism. Personality is defined as a person's characteristics and inclinations that are consistent which determine a person's psychological behavior such as ways of thinking, feeling, and acting.

Auditors tend to be more careful and careful in examining financial statements, so the failure to detect fraud will be low.

\subsection{Time Pressure}

According to Stainley \& DeZoor (2006)[25] time budget pressure is a form of pressure that arises from limitations on the resources that can be allocated to carry out and complete audit tasks. Limited resources for various situations, including profitability issues, personnel limitations, and cost constraints (Verwey \& Asare, 2016)[2].

Anggriawan (2014)[4] explains that time budget pressure is a situation that is indicated for the auditor in implementing efficiency over the time that has been prepared or there are very tight and rigid time and budget constraints. The time pressure will make the auditor have a busy time because it adjusts the tasks that must be completed with the available time. Problems will arise if it turns out that the planned time does not match the actual required time. If this happens someone will ignore the little things that are considered not important so that the time planned according to what is needed. Little things that are overlooked will certainly reduce the auditor's level of confidence that the audited financial statements are in accordance with the truth, thus allowing a gap for fraud. Someone who works under the pressure of time will lose less level than those who work without pressure.

Time pressure is defined as a constraint that occurs at the audit engagement because of limited resources in the form of time allocated to carry out all audit tasks. Time Budget Pressure is a condition where the auditor is required to make efficiency on the time budget that has been prepared, or there are time restrictions in a very tight budget (Pikirang, 2017)[26].

Indicators to measure the time pressure variable adopted from Anggriawan's (2014)[4] study with modifications, namely:

a) Functional type, states that the attitude of the auditor who uses the audit time.

b) Dysfunctional type, states the auditor's attitude to reduce attention to the qualitative aspects of indications of misstatement.

Auditors who have a functional type are better able to detect fraud. Auditors with dysfunctional types tend to miss audit evidence that shows the existence of fraudulent cues. Time budget pressures faced by professionals in the field of auditing can cause high levels of stress and affect the attitudes, intentions, and behavior of auditors. The auditor must be able to address the time budget given in conducting the audit to detect fraud. Auditors who feel burdened because of an unrealistic time budget 
might be able to easily trust the information and statements provided by the client. Although under the pressure of the budget when the auditor still must be careful in examining reports, information presented and statements by clients (Anggriawan, 2014)[4].

The auditor must be able to estimate his time especially in dividing time to work quickly in auditing and to collect audit evidence that supports the audit report. If the time allocated for completing the audit is not enough, the auditor will work quickly by not paying attention to existing audit procedures. Thus enabling the auditor can not detect fraud. Time budget is very important for planning and controlling audit tasks, therefore the auditor must be able to address the time budget given in conducting the audit so that the auditor can detect fraud.

\subsection{Hypothesis Development}

\subsubsection{Effect of Forensic Expertise on Fraud Detection}

Expertise is as a positive basis owned by a forensic auditor to support his assignment in the calculation of state losses, disclosure of hidden cases, as well as expert witnesses in court that require critical thinking, deductive analysis, communication skills in oral and written, etc. (Priantara, 2013)[19].

Forensic auditors must have academic and empirical expertise related to litigation processes and those related to investigative audits, calculation of losses and providing expert statements at court proceedings (Priantara, 2013)[19]. The auditor expertise component consists of 1) the knowledge component, which is an important component in an expertise, this component includes knowledge of facts, procedures, and experience. Experience will produce results in gathering and advancing knowledge. 2) psychological characteristics, such as the ability to communicate, creativity, the ability to work with others. Trust, communication and the ability to work together are the most important elements for audit expertise.

Research on forensic expertise conducted by Verwey \& Asare's (2016)[2] which states that consulting with forensic specialists can increase the possibility to detect the risk of fraud. Under time budget pressure, auditors without forensic expertise plan ineffective procedures. But for forensic specialists, time budget pressure does not affect the auditor's performance in planning audit procedures. Forensic expertise has an influence on fraud risk assessment. The study was strengthened by Bhasin research (2013)[17] which states that there was an effect between forensic expertise in detecting fraud.

The relationship of forensic expertise to the detection of fraud that the forensic expertise possessed by the auditor must be able to assist the auditor in conducting audits in order to find indications of fraud either caused by an error or fraud. Based on the description above, the researchers propose the following hypothesis:

H1: Forensic expertise positively affect the detection of fraud

\subsubsection{Effect of professional skepticism on fraud detection}

According to research conducted by Noviyanti (2008)[24] in her study entitled "Auditors' skepticism in detecting fraud" regarding auditor's professional skepticism in detecting fraud, the results showed that an auditor with an identity-based confidence level if given a high risk assessment of fraud has a significant effect. In this case, personality type will affect significantly the attitude of professional audit skepticism.

Another study conducted by Ramadhany (2015)[3] results of her research stated that professional skepticism had a positive and significant effect on the detection of fraud. The study was strengthened by the research of Adnyani et al.(2014)[23] which showed that there was a partial influence between the auditor's professional skepticism on the auditor's responsibility in detecting fraud and misrepresentation of financial statements.

Professional skepticism needs to be possessed by the auditor especially when obtaining and evaluating audit evidence. The auditor applies a professional skepticism when asking questions and carrying out audit procedures, not easily satisfied with less persuasive audit evidence that is only based on the belief that management and related parties are honest and have integrity (Noviyanti, 2008)[24].

The use of the auditor's professional skepticism can be used when the auditor reviews existing evidence, then detects visible or perceived fraud. Based on the description above, the authors propose the following hypothesis:

H2: Professional skepticism positively affect the detection of fraud 


\subsubsection{Effect of time pressure on fraud detection}

Time pressure is a condition that occurs when the budgeted time is less than the time available to complete the specified audit procedures. In other words, the auditor is under pressure to complete the work on time. Auditors who are under more time pressure will be less sensitive to fraudulent cues so it is less likely to be able to detect fraud

According to research conducted by Anggriawan (2014)[4] shows that time pressure negatively affects the ability of auditors to detect fraud. Auditors who are given limited time in conducting audits have a low success rate in detecting fraud.

The time pressure will make the auditor have a busy time because it adjusts the tasks that must be completed with the available time. Problems will arise if it turns out that the planned time does not match the actual required time. If this happens someone will ignore the little things that are considered not important so that the planned time is in accordance with what is needed (Anggriawan, 2014) [4].

The emergence of possible problems that occur resulted in the auditor must be able to address the time budget given in conducting the audit to detect fraud. Based on the description above, the authors propose the following hypothesis:

H3: Time pressure negatively affect the fraud detection

\section{Research Method}

\subsection{Population and Sample}

Population is a generalization area consisting of; objects / subjects that have certain quantities and characteristics determined by researchers to be studied and then drawn conclusions (Sugiyono, 2017)[27]. The population in this study were auditor employees who worked at BPKP Yogyakarta Special Province Representative. The sample is a portion of the population to be studied that can be considered to be able to describe the characteristics of the population. The sampling technique in this study is to use convenience sampling.

The reason for sampling with convinience sampling method is because it covers a wide variation in the procedure of selecting respondents where the sample units drawn are easy to contact, not troublesome, easy to measure and are cooperative in nature. So that in this study the sample chosen was the auditor who was willing to fill out the questionnaire at BPKP Yogyakarta Special Province Representative.

The data collection technique used was questionnaire. Questionnaire is a data collection technique that is done by giving a set of written statements to respondents to be answered (Sugiyono, 2017)[27]. The questionnaire distributed had been arranged in a structured manner in accordance with the object of research to be studied. Distribution of questionnaires was also included with a cover letter with an explanation of the purpose of the study. The questionnaire also includes clear filling instructions to make it easier for respondents to provide correct answers. The results of the questionnaire were measured using an interval scale with a 4-point scale ranging from strongly disagree (1), disagree (2), agree (3), strongly agree (4).

\subsection{Data analysis Method}

This study uses multiple linear regression analysis method which aims to examine the relationship of the influence of the influence of independent variables on the dependent variable. The calculation analysis used is multiple linear regression analysis with the dependent variable being the detection of fraud and the independent variables are forensic expertise, auditor professional skepticism and time pressure. Multiple linear regression to measure the effect of more than one independent variable on the dependent variable (Ghozali, 2013: 101)[28]. The equation model can be described as follows:

$$
\mathrm{Y}=\mathrm{a}+\mathrm{b} 1 \mathrm{X} 1+\mathrm{b} 2 \mathrm{X} 2+\mathrm{b} 3 \mathrm{X} 3+\mathrm{e}
$$

$\mathrm{Y}:$ Detection of fraud

$\mathrm{X} 1$ : Forensic expertise

$\mathrm{X} 2$ : Professional Skepticism

X3: Time Pressure 

a : Constants
b : Regression coefficient
e : Error

\section{Result}

This research was conducted on auditors working in the Financial and Development Supervisory Agency (BPKP) of the Yogyakarta Special Province Representative. The process of licensing, distributing and returning the questionnaires was carried out from April 17, 2018 until May 22, 2018. The questionnaires distributed amounted to 88 pieces and the number of returned and can be processed amounted to 55 pieces. An overview of sample data is presented in table 1.

Table 1. Research Sample Data

\begin{tabular}{lcc}
\hline & Number & Percentage (\%) \\
\hline Questionaire spread-off & 88 & 100 \\
Questionaire return & 60 & 68.2 \\
Questionaire is not return & 28 & 31.8 \\
Defect & 5 & 5.6 \\
Questionaire processed & 55 & 62.5 \\
\hline (Source: processed data 2018) & &
\end{tabular}

This study uses the average value (mean), maximum value, minimum value and standard deviation to describe the statistical description of each variable. Statistical descriptions of the descriptions are presented in table 2.

Table 2. Descriptive Statistics

\begin{tabular}{lccccc}
\hline & $\mathrm{N}$ & Minimum & Maximum & Mean & Std. Deviation \\
\hline forensic expertise & 55 & 27 & 36 & 32.69 & 2.559 \\
professional skepticism & 55 & 24 & 32 & 29.25 & 2.92 \\
time pressure & 55 & 8 & 16 & 11.58 & 2.507 \\
Fraud Detection & 55 & 30 & 40 & 34.8 & 3.106 \\
\hline
\end{tabular}

(Source: processed data 2018)

The results of testing the validity carried out showed that all variables have a value correlated item-total correlation> $\mathrm{R}$ table $(0.1975)$ so that the indicators for all variables can be said to be right (valid) as a measurement tool. While the results for reliability testing show that for all variables have a Cronbach Alpha value> 0.60. This means that the question items in the questionnaire for all variables can be said to be consistent or reliable as a measurement tool. The reliability test results are presented in table 3.

Table 3. Reliability Test

\begin{tabular}{lcc}
\hline \multicolumn{1}{c}{ Variable } & \multicolumn{2}{c}{ Cronbach's Alpha } \\
\hline Forensic expertise (X1) & 0,755 & Reliable \\
Professional skepticism (X2) & 0.881 & Reliable \\
Time pressure (X3) & 0,825 & Reliable \\
Fraud Detection (Y) & 0,841 & Reliable \\
\hline (Source: processed data 2018) & &
\end{tabular}

The normality test results also show that the regression model obtained is normally distributed, which shows that the data distribution is around the diagonal line. In addition, normality test results can also be seen using the Kolmogorov-Smirnov Test One Sample method. The basis for decision making is based on probability (Asymptotic Significance), namely: if the probability is> 0.05 then the distribution of the population is normal, and vice versa. Based on the calculation results show that the Kolmogorov-Smirnov value can be known that all variables have sig values. $>0.05$, this means that all data are normally distributed. The results of the normality test are presented in table 4 . 
Table 4. Normality Test

\begin{tabular}{lll}
\hline One-Sample Kolmogorov-Smirnov Test & & Unstandardized Residual \\
\hline $\mathrm{N}$ & & 55 \\
Normal Parameters a,b & Mean & 0 \\
& Std. Deviation & 0.250000332 \\
& Absolute & 0.074 \\
Most Extreme Differences & Positive & 0.063 \\
& Negative & -0.074 \\
Kolmogorov-Smirnov Z & & 0.549 \\
Asymp. Sig. (2-tailed) & & 0.924 \\
a. Test distribution is Normal & \\
b. Calculated from data & & \\
\hline (Source: processed data 2018) &
\end{tabular}

Multicollinearity test results showed that all independent variables had a VIF value $<10$ and had a Tolerance value> 0.10 . Thus, it can be concluded that there are no symptoms of multicollinearity. The results of multicollinearity testing are presented in table 5.

Table 5. Multicollinearity Test

\begin{tabular}{lll}
\hline Model & Collinearity Statistics & \\
& & \\
& Tolerance & VIF \\
\hline (Constant) & & \\
forensic expertise & 0.668 & 1.497 \\
professional skepticism & 0.701 & 1.427 \\
time pressure & 0.845 & 1.184 \\
Dependent Variable: Fraud detection & \\
(Source: processed data 2018) & &
\end{tabular}

Hypothesis testing is done by determining the coefficient of determination, multiple linear regression, and t model tests. First, the determination coefficient test which aims to determine how much the independent variable (forensic expertise, professional skepticism and time pressure) can explain the dependent variable (fraud detection). The results of testing the coefficient of determination is presented in table 6.

Tabel 6. Result Determination-Coefficient

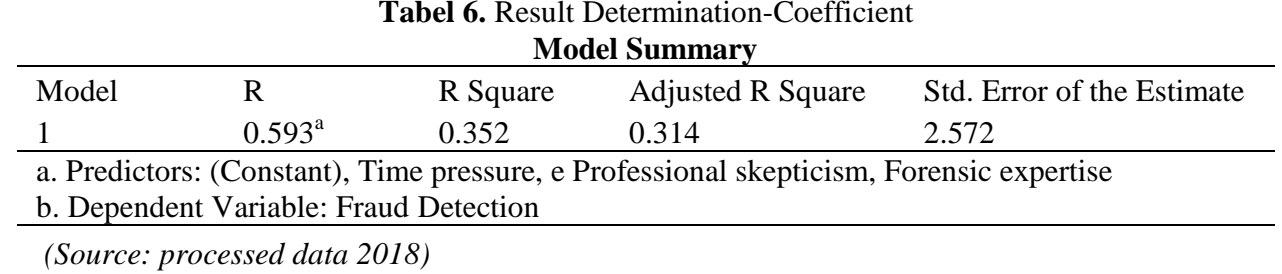

Based on table 5 above, the coefficient of determination (R2) of 0.314 means that forensic expertise, professional skepticism and time pressure have an effect of $31.4 \%$ on the detection of fraud, while the remaining $68.6 \%$ is explained by other variables outside the study. Second, multiple regression testing and $\mathrm{t}$ test were performed. The results of multiple linear regression testing and tests are summarized and presented in table 7 below.

Table 7. Result Summary

\begin{tabular}{llrl}
\hline & \multicolumn{1}{c}{ B } & $\mathrm{t}$ & \multicolumn{1}{c}{ Sig } \\
\hline (Constant) & 9.569 & 1.968 & .055 \\
Forensic Expertise & .358 & 2.138 & .037 \\
Professional Skepticism & .357 & 2.492 & .016
\end{tabular}




\begin{tabular}{llll} 
Time Pressure & .267 & 1.757 & .085 \\
\hline (Source: processed data 2018) & &
\end{tabular}

The results of testing the first hypothesis shows the value of tcount is $2.138>$ of the ttable value of 2.006 with a significance probability of $0.0377<0.05$. This means that the first hypothesis namely forensic expertise positively affect the detection of fraud, so the first hypothesis is accepted.

The results of the second hypothesis test show the value of tcount is $2.492>$ from the table value of 2.006 with a significance probability of $0.016<0.05$. This means that the second hypothesis namely professional skepticism positively affect the detection of fraud, so that the second hypothesis is accepted.

The results of the third hypothesis testing showed a positive coefficient of 0.267 , a calculated value of 1.757 <from a table value of 2.006 and a significance probability of $0.085>0.05$. This means that the third hypothesis namely time pressure negatively affect the detection of fraud is rejected.

\section{Discussion}

\subsection{Forensic Expertise Positively Affect Fraud Detection}

Forensic expertise has a positive effect on the detection of fraud. The results of this study are in line with the results of previous studies conducted by Bhasin (2013)[17] which concluded that there is an influence between forensic skills in detecting fraud. The results of the study are also in line with the results of research conducted by Verwey \& Asare (2016)[2] which states that there is a positive influence in consulting with forensic specialist in increasing the risk of fraud.

In the theory of attribution of forensic expertise possessed in an auditor can detect fraud. This is an internal factor that comes from within an auditor. The higher forensic expertise in the auditor will increase the ability of auditor in detecting fraud.

\subsection{Professional Skepticism Positively Affect Fraud Detection}

Professional skepticism positively affect the detection of fraud. This means that the higher the level of professional skepticism an auditor has, the auditor's ability to detect fraud tends to be higher. Conversely the lower the experience possessed by an auditor, the auditor's ability to detect fraud tends to be lower. The results of this study support research conducted by Ramadhany (2015)[3], Adnyani et al. (2014)[23], Widiyastuti (2009)[29], Noviyanti (2008)[24] who found that professional skepticism had a positive effect on the detection of fraud. Auditors should have a high attitude of skepticism because a high attitude of skepticism will make the auditor have a great desire to find information related to symptoms of fraud, skepticism is needed especially if there are indications of fraud in the entity being audited and without professional skepticism fraud tends to be ignored, because fraud usually hidden by the perpetrators (Ayu et al., 2016)[30]. With professional skepticism the auditor automatically has questions, and the awareness that fraud can occur at any time and place. This study found that auditor's professional skepticism influences the detection of fraud, so in conducting the auditing process the auditor must be able to maintain his professional skepticism so as to make it easier for auditors to find fraud in a financial statement that they examine. The auditor should not immediately trust all the evidence he gets in the auditing process. By having a high attitude of skepticism, the auditor tends to expand the area of his examination so as to find evidence that is competent enough to convince him that the financial statements examined are free from any indication of fraud. This shows that the higher the attitude of professional skepticism that auditors have, the more it can help in detecting fraud.

\subsection{Effects of Time Pressure on Fraud Detection}

Time pressure has no effect on fraud detection. The results of this study are in line with research conducted by Pikirang (2017)[26], Pangestika (2014)[5], Rustiarini (2013)[6] and Fitriany (2011)[31], that time budget pressure does not affect fraud detection. The results of the study are not in line with research conducted by Anggriawan (2014)[4] which states that time pressure negatively affects the ability of auditors to detect fraud. Time pressure in conducting an audit affects the success of the auditor in detecting fraud. This is because in carrying out every assignment given by an auditor, he/she already has a time allocation that is adjusted to the complexity of the tasks given so that the auditor must be able to carry out the tasks given efficiently (Pikirang, 2017)[26]. This result also shows that although the auditor 
is faced with the problem of time pressure, the auditor actually gives a positive response by doing the best work within the time limit given (Rustiarini, 2013)[6]. In this case the time budget would encourage and provide challenges for auditors to work more actively, actively, and selectively in evaluating information so that it can detect fraud.

In the theory of time pressure attribution which is one of the conditions that can affect auditors in detecting fraud. This is an external factor originating from outside or circumstances that can affect the auditor in detecting fraud. From the results of the study indicate that external time pressure factors do not affect the auditor in the detection of fraud.

\section{Conclusion and Implication}

\subsection{Conclusion}

The ability of auditors to detect fraud is needed in order to prevent fraud in the future. Based on the discussion of the results of data analysis in this study it can be concluded that forensic expertise and professional skepticism positively affect the fraud detection. However, time pressure does not affect auditors in detecting fraud.

\subsection{Implication}

This proves the importance of training related to forensic knowledge for auditors working at BPKP Yogyakarta and also the experience of doing audit of auditors is necesarily needed to raise the sense of skepticism. If all auditors already have forensic expertise, it is very useful to detect fraud. So this will improve the performance of the government's internal auditors and easily assist the Corruption Eradication Commission or the KPK in eradicating fraud perpetrators. In addition, auditors who work at BPKP in order to maintain professional skepticism that is owned by an auditor and always be careful in order to obtain evidence.

\section{References}

[1]T. I. Indonesia, “Corruption perceptions index 2017.” 2018.

[2]S. K. Verwey, I. \& Asare, "The effect of forensic expertise and time pressure on fraud risk assessment and responsiveness," SSRN Electronic Journal.

[3]F. Ramadhany, "Influence of experience, independence, professional skeptism, competence and communication of kap interpersonal auditors against fraud detection," JOM FEKON, vol. 2, no. 2, pp. 1$15,2015$.

[4]F. Anggriawan, E., "The effect of work experience, professional skeptism, and time pressure on the auditor in detecting fraud," Jurnal Nominal, vol. III, pp. 101-116, 2014.

[5]W. Pangestika, "Effects of professional skills, independence, and time budget pressure on fraud detection," JOMFEKON, vol. 1, no. 2, pp. 1-15, 2014.

[6]N. W. Rustiarini, "Effects of task complexity, time pressure, and personality traits on performance," MAKARA of Social Science Humanities Series, vol. 17, no. 2, pp. 126-138, 2013.

[7]F. Heider, The psychology of interpersonal relations. Hoboken, NJ, US: John Wiley \& Son Inc, 1958.

[8]A. Kreitner, R., \& Kinicki, Organization behavior, 9th ed. Jakarta: Salemba Empat, 2014.

[9]Sastiana., "The effect of forensic audit and auditor professionalism on fraud prevention with spiritual intelligence as a moderating variable in BPKP of South Sulawesi Province," Jurnal Ilmu Akuntansi Peradaban, vol. 1, no. 1, pp. 106-127, 2016.

[10]O. A. Chad \& Albrecht, W. S., Fraud examination and prevention. Mason, OH: Thomson/SouthWestern, 2004.

[11]I. A. P. Indonesia, Standar Audit.

[12]R. Arens, Alvin A., \& Mark, Auditing and assurance service. Jakarta: PT. Gelora Aksara Ratama, 2006.

[13]ACFE, Examination manual. 2006.

[14]F. Muchlis, "The effect of expertise components on the auditor's ability in detecting fraud on the auditor BPKP West Sumatera,” JOMFEKON, vol. 2, no. 1, pp. 1-16, 2015.

[15]Karyono, Forensic Fraud. Yogyakarta: Andi Offset, 2013.

[16]A. S. Kayo, Forensic audit: use and competence of auditors in eradicating corruption, 1 st ed. Yogyakarta: Graha Ilmu, 2013. 
[17]D. M. Bhasin, “An emperical investigation of the relevant skills of forensic accountants: experience of a developing economy," European Journal Accounting, Auditing and Financial Research, vol. 1, no. 2, pp. 11-52, 2013.

[18]J. A. DiGabriele, “An empirical investigation of the relevant skills of forensic accountants," Journal of Education of Business, vol. 83, no. 6, pp. 331-338, 2008.

[19]D. Priantara, Fraud auditing \& investigation. Jakarta: Mitra Wacana Media, 2013.

[20]D. Sudaryati, "Forensic auditing and value for money audit," E-Journal Universitas Muria Kudus, vol. 1, no. 1, pp. 1-17, 2010.

[21]M. A. Alabdullah, T.T. Y., Alfadhl, M. M. A., Yahya, S., \& Rabi, A, "The role of forensic accounting in reducing financial corruption: A Study in Iraq," International Journal of Business and Management, vol. 9, no. 1, pp. 26-34, 2013.

[22]T. Tuanakotta, Contemporary audit. Jakarta: Salemba Empat, 2015.

[23]N. T. Adnyani, N., Atmadja, A. T., \& Herawati, "The effect of auditor professional skeptism, independence, and auditor's experience on auditor's responsibility in detecting fraud and fraudulent financial statements," E-Journal, Universitas Pendidikan Ganesha, vol. 2, no. 1, pp. 1-11, 2014.

[24]S. Noviyanti, "Professional auditor skepticism in detecting fraud," J. Akuntansi dan Keuangan Indonesia, vol. 5, no. 1, pp. 102-125, 2008.

[25]F. T. Stanley, J. D., \& DeZoort, "Audit firm tenure and financial restatement: an analysis of industry specialization and fee effects," Journal of Accounting and Public Policy, vol. 26, pp. 131-159, 2007.

[26]J. Pikirang, "Effects of auditor's time pressure, independence and ethics on audit quality in the inspectorate office, Sangihe Islands Regency,” Jurnal Riset Akuntansi Going Concern, vol. 12, no. 2, pp. 717-732, 2017.

[27]Sugiyono, Quantitative, qualitative research methods and R\&D. Bandung: Alfabeta, 2017.

[28]I. Ghozali, Aplikasi Analisis Multivariate dengan Program IBM SPSS21. Semarang: Badan Penerbit UNDIP, 2013.

[29]M. Widiyastuti, "Effect of Competence, independence and professionalism on the auditor's ability to detect fraud," Jurnal Akuntansi Universitas Diponegoro Semarang, vol. 5, no. 2, pp. 52-73, 2009.

[30]I. D. I. Ayu, I., Biksa, I., \& Wiratmaja, "Effects of auditor's professional experience, independence, skepticism on fraud detection," E-Jurnal Akuntansi Universitas Udayana, vol. 17, 2016.

[31]Fitriany, "Analysis of factors affecting auditor job satisfaction and its relationship with auditor's performance and desire to change work," Jurnal Akuntansi dan Keuangan Indonesia., vol. 8, no. 2, pp. 171-196, 2011. 